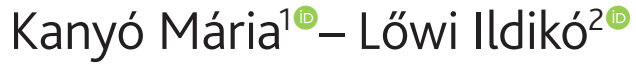

\section{A szimbólumok egyetemes értékmegőrző szerepe}

The Universal Value Preserving Role of Symbols

\begin{abstract}
Absztrakt
A szimbólumok az emberi közösségek kultúrájának szerveződésében meghatározó fontosságú elemek. Minden társadalom szimbólumrendszere kulcsszerepet játszik értékei, céljai megjelenitésében, a közösségi identitás megteremtésében, valamint egyik legföbb eszköze a tradicionális tapasztalatok továbbadásával a kultúra átörökitésében. Dolgozatunkban azt vizsgáljuk, milyen célok mentén születnek a szimbólumok, a társadalmi, illetve a szervezeti kultúra jelentéshordozóiként hogyan válnak a csoportazonosulás kifejezőivé, valamint milyen folyamatok során lesznek a társadalomértelmezés legfontosabb eszközei.
\end{abstract}

Kulcsszavak: szimbólum, szervezeti szimbolizmus, kulturális átörökités, természetes és mesterséges szimbólumok

\section{Abstract}

Symbols are significant elements in the cultural organisation of a community. They are also the guardians of tradition. Every symbolic system of the society plays a highly important role in the creation of public identity. One of their most important tools is the traditional experience in the transmission of culture. In our study, we are analysing the data regarding the aims of the symbols. They are the carriers of the societal and the systematically cultural meaning, therefore, it is important to mention, what processes will be the most important tools for the social interpretation.

Nemzeti Közszolgálati Egyetem Hadtudományi Doktori Iskola, PhD c. egyetemi tanár, szerződéses oktató - University of Public Service Doctoral School of Military Sciences, PhD Honorary Professor, visiting lecturer, e-mail: kanyo.maria@ uni-nke.hu

2 Nemzeti Közszolgálati Egyetem Hadtudományi Doktori Iskola, doktori hallgató - University of Public Service, Doctoral School of Military Sciences, PhD student, e-mail: ildikolowi@t-email.hu 
Keywords: symbol, organisational symbol, cultural transmission, natural and artificial symbols

\section{Bevezetés}

A szimbólumok taglalása előtt szükségesnek látjuk a társadalomtudományok területén napvilágot látott - eltérő szemléletet magában foglaló - szimbólumértelmezések közül néhányat felvillantani. Mead szimbólumokról alkotott nézete szerint (idézi Preglau) az emberi viselkedés jelképesen közvetített interakciók sorozata, amelyböl a tudat, az egyén és a társadalom is keletkezett. ${ }^{3}$ Cassirer a szimbolikus formák közé sorolta a nyelvet, a mítoszokat és a művészetet, amely szellemi képződményekben közös, hogy alapvetően emberközpontú jellegűek, és az egyedüli viszonyítási pont közöttük az ember. ${ }^{4}$ Habermas szerint egy szimbolikus megnyilvánulás megértése mindenekelőtt a megértés folyamatában való részvételt követeli meg, és ezért a jelentések csak belülről tárhatók fel. ${ }^{5}$ Ricoeur megfogalmazásában a szimbólum olyan jeleket feltételez, amelyeknek már van elsődleges, szó szerinti, kézzel fogható értelmük, $s$ amelyek ezen értelem által egy másik értelemre utalnak. ${ }^{6}$ Jung a szimbólumokat az emberrel veleszületett ősképeknek, archetípusoknak tartja, amelyeket az emberiség közös múltjában szerzett tapasztalatainak elraktározott örökségével magyaráz. A kulturális-vallási szimbólumok szellemiségünk fontos alkotóelemei, az emberi közösségek éltetőerejét képezik, gyökeres kiirtásuk súlyos veszteségekkel járna. ${ }^{7}$

White megfogalmazásában egyenesen a szimbólumhasználat tette az embert emberré, hiszen minden emberi viselkedés jelképes viselkedés, amelyet az adott embercsoport maga ruház fel jelentéssel. A társadalom, de egy kisebb emberi közösség (mint például egy szervezet) kultúrája is csak szimbólumok segítségével létezhet, léte megörzését szolgálja a kulturális hagyomány, amely viszont megmagyarázza az adott szociális közegben az emberi viselkedést. ${ }^{8}$

Minden civilizáció a szimbólumok használata által született és maradt fenn. Ha egy kultúra alapegységeit annak szimbólumai alkotják, mint ahogy Geertz állítja, úgy minden kulturális esemény egy jelképes rendszer része, és az egyes kultúrák szükségképpen különböző gondolkodási modelljei eltérő szimbólumértelmezéseket foglalnak magukban. ${ }^{9}$ Lévi-Strauss nyomán (idézi Pál) minden kultúrát jelképes rendszerek összességeként is meghatározhatunk. ${ }^{10}$

$3 \quad$ Friedold Preglau: Szimbolikus interakcionizmus - George Herbert Mead. In Julius Morel et alii: Szociológiaelmélet. Osiris, Digitális Tankönyvtár, 2000. 70-71.

Ernst Cassirer: A szimbolikus formák filozófiája. In A jel tudománya. Budapest, Gondolat, 1975. 91-96.

Jürgen Habermas: A kommunikatív cselekvés elmélete I-II. Kézirat. Budapest, Eötvös Loránd Tudományegyetem, 1985. 19-22.

6 Pierre Ricoeur: A hermeneutika elmélete. Tanulmányok. Auerbach, Palmer, Ricoeur, Hirsch, Szondi, Frye, Kermode-szöveggyüjtemény. (Fabiny Tibor szerk.) Szeged, JATEpress, 1998. 189.

7 Carl Gustav Jung: Mélységeink ösvényein. In Az anyaarchetípus lélektani aspektusai. A szimbólumok szerepe. Budapest, Gondolat, 1993. 106.

8 Leslie White: Az energia és a kultúra evolúciója. In Kisdi Barbara: A kulturális antropológia története, elméletei és módszerei. Budapest, Pázmány Péter Katolikus Egyetem - Akadémiai, 2012. 125.

9 Clifford Geertz: Az értelmezés hatalma. Antropológiai irások. Budapest, Osiris, 2001. 65.

10 Pál József - Újvári Edit: Jelképek, motívumok, témák az egyetemes és a magyar kultúrából. Szeged, Balassi, 2005. 
Az embert szimbólumteremtő lénynek nevezi a szakirodalom, a szimbólumképzés az ember megkülönböztető jegye..$^{11}$ Durkheim szerint „a társadalmi élet, minden vonatkozásban és történelme minden pillanatában, csakis kiterjedt szimbolizmussal lehetséges". 12

Az emberiség szellemi múltjában megőrzött sokszínű képzet, szertartás és hagyomány (például az évkörhöz füződő rítusok, a termékenység elősegítéséhez kapcsolható kultuszok, a jó és a rossz erők harcának szimbolizálása) mind egyetemes, örökérvényü törvényszerűséget ír le, jelképek segítségével. A szimbólumok rendszerei nemcsak a korai közösségek életében játszottak fontos szerepet, de ma is körülvesznek bennünket, még ha nem is minden esetben tudatosul bennünk, hogy bizonyos információk szimbólumok közvetítésével jutnak el hozzánk. Mindennapjainkat átszövik a nemzeti, vallási, politikai jelképek, a nyelvünk, a betük, a számok hordozta jelentések, az otthonunkat díszítő különböző motívumok, valamint a munkahelyek szimbolikája a céglogóktól az egyenruháig. A modern társadalmakat a szervezetek társadalmának szokás nevezni, s a szervezetek müködése során is a szimbólumok széles tárházával találkozunk.

\section{A szimbólumok állandósága és változása}

A legkorábbi időktől kezdve a szimbólumok közvetítői voltak annak a szerves kultúrának, amelyben megszülettek, és amelyben eredeti jelentésüket elnyerték. Később a kialakult szimbolikus rendszer íratlan szabályait és a kultúrában felhalmozódott ismereteket írásban is rögzítették, így az elődök által megőrzött tapasztalatokból, a régi hagyományokból minden következő társadalom fontos igazodó normákat tudott meríteni, amelyeknek közösségformáló ereje vitathatatlan volt. A jelképek világának meghatározó jellegzetessége a hagyományozódás, amelyet a közösséghez tartozó egyén a szocializációs folyamat során képességeinek és lehetőségeinek megfelelően passzívan, illetve tevékenyen vesz át.

A történelem során a különböző kultúrák egymásra hatása következtében előfordult a szimbólumok egyes elemeinek összeolvadása, jelentésének elmozdulása, ami a hagyományos formai elemeknek más tartalommal való feltöltődését eredményezte. A ritka példák egyike a buddhizmus és vallási szimbólumainak elterjedése a Távol-Keleten, majd a helybeli szakrális kultuszok és ikonográfiai elemek ezt követő áthangolódása. Az ókeresztény múvészetnek szintén jellegzetes vonása az antik motívumoknak a keresztény müvészetbe való integrálódása. Az eltérő szimbólumalkotás köznapi megjelenésének tekinthető a kövér has kultúrától függő pozitív, illetve negatív szimbolikus jelentése. A japánok szemében az energiát, a tudást szimbolizálja, Kínában a gazdagságot, míg a nyugati fejlett országok kultúrájában a lustaság, falánkság, igénytelenség jelképe. ${ }^{13}$

11 Csörgő Zoltán: A szimbólumok és szertartások szerepe a modern kori ember életében. Debrecen, Debreceni Kossuth Lajos Tudományegyetem, 2011. 10.

12 Emile Durkheim: A vallási élet elemi formái. A totemisztikus rendszer Ausztráliában. Budapest, L'Harmattan, 2003. 217.

13 Szabó Réka: Metaforák és szimbólumok: C. G. Jung szimbólumértelmezésének és a fogalmi metaforák elméletének összevetése. PhD-értekezés. Pázmány Péter Katolikus Egyetem, 2012. 71. 
Egy-egy történelmi korszak szimbólumai, azok sajátosságai mindig az adott időperiódus szimbolikus kifejeződései, és a jelképek az éppen uralkodó társadalom (politikai berendezkedés) domináns szemléletét tükrözik. A Kapitány szerzőpáros szerint viszont nincs egyetlen olyan „korszakjellemző” sem, amely mindenkire érvényes volna. A változások jogosan tekinthetők a korszakváltás szimbolikus jeleinek, az előtérbe kerülő, illetve újonnan keletkezett, új arcot öltő tárgyak, jelenségek, egy új korszak szimbólumainak..$^{14}$ Előfordul, hogy adott korszak szimbólumai később, már csak bizonyos csoportok számára örzik üzenetüket, azaz jelentik az eredeti tartalmat, míg más csoportok más tartalmat kapcsolnak az adott szimbólumhoz. Elég arra gondolni, hogy a házikönyvtár mint az értelmiségi lét, a kulturáltság jellegzetes lakástartozéka - amely a magasabb társadalmi státusz elérése megbecsült eszközének szimbolikáját hordozza - napjainkban nem minden csoport számára közvetíti ezt az üzenetet. Bizonyos csoportoknak a lakás könyvei nem a siker, a tudás hordozói, sokkal inkább „porfogók”, a meghaladott múlt haszontalan tárgyai, és helyükbe más szimbólumok (döntően a jólétjelző tárgyak) lépnek a siker, az életben elért státusz megjelenítőiként.

A történelem folyamán az egyes népek által megjelenített szimbólumok igen változatosak, és a fejlettebb társadalmakban több szimbólumegyüttessel való azonosulás lehetősége kínálkozik mind a kognitív, mind az expresszív szimbólumok terén. Mindazonáltal az adott - legyen az társadalmi vagy szervezeti - kultúra centrális értékeit megjelenítő szimbólumok jelentéstartalmával történő kollektív azonosulásnak nagy jelentősége van, ezért az e szimbólumokat figyelmen kívül hagyók, a közösség szemében „körön kívül” kerülnek. Különösen a primitív társadalmakban ügyeltek a szimbólumok fenntartására, őrzésére, például a korai jávai népeknél a közös tudattartalmat megjelenítő szimbólumokat még kritikával sem lehetett illetni, az esetlegesen kritizálókat „még nem jávai, s mivel még nem jávai, még nem is egészen ember"-nek tartották. ${ }^{15}$

A nagy történelmi korszakok jelképrendszerének értelmezésekor világosan kimutatható a kor kulturális foka, jellege és a jelképeket használók világhoz való viszonya. Miután az emberi közösség számára fontos kollektív érzések csak valamely anyagszerü tárgyon rögzülve képesek tudatosulni és fennmaradni, ezért a korai társadalmak ezen érzések „megörökítése" végett fakéregbe véstek képet, vagy szoborformájú képeket (például földből) mintáztak, de akár geometriai rajzok is szolgálhatták az érzések kifejezését, az egyetlen feltétel, ami mindben közös, hogy ezeknek a szimbólumoknak megállapodásszerü értelme volt a közösségben. Az őskor szimbolikáját legföképpen az állatábrázolások jellemezték, a növények és emberek rajzolása csekélyebb mértékben fordult elő. A primitív népeknél az állat nemcsak az életben maradás záloga, hanem a világképük elképzelésének fontos kelléke is volt, mert a barlangrajzok állatai a mágikus rítus résztvevőivé váltak. Amely szimbólumok az adott ősi közösség számára fontos jelentéssel bírtak, azokat megőrizték és tovább hagyományozták. Az univerzális jelképek biztosították a kultúrák közötti átjárhatóságot, így segítve

\footnotetext{
Kapitány Ágnes - Kapitány Gábor: Résztvevő megfigyelés a saját társadalomban - korszakok szimbolikája. In Boglár Lajos et alii: A magyar kulturális antropológia története. Budapest, Nyitott Könyvmühely, 2008. 23.

15 Geertz (2001) i. m. 10.
} 
azok fennmaradását. A korai kultúrák szimbólumai nem tűntek el, csak átalakultak és aktualizálódtak, a kornak megfelelő, megváltozott jelentéstartalommal. ${ }^{16}$

Az ókori szimbólumok erősen kötődtek az egyiptomiak mitológiájához, jelképeken keresztül történt a fontosabb jelentéstartalmak értelmezése. Az ókori civilizációk mágikus ceremóniáit az állatkultuszuk jelentősen meghatározta. Az állat az ember ösztönének, ösztönös lelkének jelképeként vált szimbólummá. ${ }^{17}$ Az oroszlán mindig a dicsőség, bátorság, hatalom, erő szimbólumaként, míg a bárány az áldozat, a szelídség jelképeként maradt fent az ókorból az egyetemes szimbolikus hagyományokban.

Az antik és a keresztény hagyományokat ötvöző középkori európai - beleértve a magyar - müvelődés egész történetén végigvonult a jelképek újrafogalmazása, aktualizálása. Az európai múvészetet és műveltséget meghatározó Biblia transzcendens tartalmainak szimbólumokban való kifejezése a múvészeteket, úgy az irodalmat, mint zenét és a képzőművészetet, sőt a filmművészet alkotásait is átszövik - olvasható Pál és Újvári Szimbólumszótárában. A kereszténység jól tovább örökíthető jelképrendszerének gyökerei a „pogány”-nak nevezett vallásokig nyúlnak vissza. ${ }^{18}$

A középkorban, a reneszánsz idejének hajnalán a képi ábrázolás jelentősége a kor kultúrája érdeklődésének a középpontjába került. Az ókor motívumait és témáit időszerüsíteni kellett a reneszánsz kulturális világképnek megfelelően. Ebben nagy szerepet vállaltak a reneszánsz képzőművészek, hihetetlenül magas színvonalú alkotásaikkal. Panofszky szavaival élve „kétségtelen, hogy minden stílusban megvan a kifejezett tartalmaknak egy jól meghatározott köre, melyben egy meghatározott korhangulat és életfelfogás tükröződik, a szimbólumok világa által".19

A közép-kelet-európai régió nemzeti szimbólumai a 18. század legvégén kiemelt szerepet játszottak a nemzeti identitás kialakulásában. A magyarság önazonossághoz kapcsolódó szimbólumainak száma nagyon jelentős, közülük is kiemelkedik a nemzeti identitást erősitő Szent Korona-elmélet és a magyar koronához füződő szimbólumok újraéledése. Teszelszky (idézi Bodnár) tézise szerint ugyanis a kora újkori szétszabdalt Magyarország történetében a Werbőczy által aktualizált koronahagyomány fokozatos térnyerése, alakváltozása, majd politikaelméletté formálódása teremthette meg azt a kulturális-politikai alapot, amelyben a magyarság szimbólumai önazonosságot képező tényezővé váltak. ${ }^{20}$

A 20. század közepére a szimbólum jelentősége egyre nyilvánvalóbb lett, mert egy ismert szimbólum alakjában egyszerre több múltbeli kor hagyományai fedezhetők fel, és mert egy-egy jelkép egyszerre tartalmaz általános-tipikus és konkrét-egyedi társadalmi/kulturális elemeket. A Kapitány szerzőpáros a tipikus amerikai életforma szimbólumának példájaként a Coca-Cola jelenséget említi, amely egyrészt az amerikai társadalom világán belül maradva a korlátlan lehetőségeket, az „amerikai álom” megvalósíthatóságát jelképezte a vasfüggöny idején, másrészt a fejlettséget, a Nyugatot,

16 Mohai Zsófia: A középkor szimbolikája. Ars Ensis, 2015. 6-9.

17 Váraljai Julianna: Egyiptomi szimbólumok, amiket ma is használunk. HarmoNet, 2019. december 15.

18 A hármas a Szentháromságot és az erényeket jelképezte, a négyes az évszakokat, égtájakat, alapelemeket. A három és négy összege és szorzata a keresztény szimbolikában: a hét főbünt, és a tizenkét apostolt jelképezi. A kék szín Mária attribútuma volt, a galamb, hal a kereszténységre, sárkány az ördögre, kígyó a csábításra utalnak. Lásd Pál-Újvári (2005) i. m.

19 Erwin Panofsky: A jelentés a vizuális müvészetekben. Tanulmányok. Budapest, ELTE BTK, Művészettörténeti Intézet, 2011. 4.

20 Bodnár-Király Tibor: A magyar korona jelentésének színeváltozása a kora újkorban. Századvég, 15. (2009), 54. 149-154. 
a szabadságot szimbolizálta a kelet-európai ember számára. ${ }^{21}$ Korunkban éppúgy, mint a korábbi történelmi korok társadalmaiban, kollektív képzetekkel, olyan erényekkel, tulajdonságokkal ruházhatnak fel dolgokat, ami azt különlegessé, kívánatossá (esetleg követendővé) teheti, miközben a valóságban nincs, ami ezt megalapozná. Számos vállalkozás, gazdasági szervezet terméke, szolgáltatása tulajdonképpen a hozzáadott jelentéstartalmat szimbolizálja. Hankiss a szimbólumok korunkban megnövekedett jelentőségéről ír, vizsgálati szempontja: a meghaladott értékek és világmagyarázatok helyett kínált új tartalmak. Nézete szerint a tárgyaknak, jelenségeknek mindig is volt szimbolikus tartalma, azonban a fogyasztói civilizációban a szimbolikus tartalmak kerültek elötérbe az élet számos területén, amihez a reklámipar és a média hathatós „segítséget ad". Véleménye, hogy modern társadalmunkban, az árukban a szimbolikus tartalom szerepe az „anyagi-fizikai érték” rovására megnőtt, így egyre többet fizetünk a szimbolikus tartalomért. ${ }^{22}$

A szimbólumrendszerek történelmi korokban való megjelenése és változása során láthatóvá vált, hogy az egyes korszakokban születő szimbólumok nem szemlélhetők egymástól elszigetelten. A korábbi korszakok jelképi világa áthagyományozódott és kimutatható a jelenben is. A korszakok alapegysége és kifejezője a szimbólum lesz, következésképpen a történelmi korszakok maguk is szimbólumokká válhatnak, és bár a szimbólum tartalmazza a jövőt, jövőbeli korok alakulását a szimbólumok alapján elöre megjósolni szinte lehetetlen.

\section{A szimbólumok müködése és modern kori kulturális jelenléte}

A szimbólumok mechanizmusának müködésére több, döntő jelentőségű tényező lehet befolyással. A szimbólumok a társadalmi mechanizmusok „összekötő láncszemei”, amelyek üzenetet hordoznak a múltból, és információt kínálnak a jövőre nézve. Minden egyes szimbólum egy olyan ablak, amely rálátást nyújt a társadalom egészre, de megmutatja az egyéni használók belső világát, identitását, konfliktusait és azok kezelési módjait. Így válhat a szimbólum a társadalomértelmezés alapegységévé és az értelmezés legfontosabb eszközévé. ${ }^{23}$ További funkciójaként a társadalom integrációjában szerepet játszó „kollektív tudat”, s az ehhez párosuló érzelmek szimbolikus megjelenítésben nyernek kifejezést. „Egyébként szimbólumok nélkül a társadalmi érzések csak ideig-óráig maradhatnának fönn." ${ }^{24}$ Ezek az érzések azért tudnak erősek maradni, mert folyamatos fenntartásukat, az ezen érzéseket kifejező közösségi események (cselekvések, nyelvi, képi kifejezések) szüntelenül felidézik. Minden kor és minden szociális közösség társadalma a számára centrális értékek ébrentartását kiterjedt szimbolizmussal vigyázza.

A szakirodalom nagyra értékeli a szimbólumokban rejlő azonosság és ellentétesség kettősségét és a használókra gyakorolt hatását. Jó példa lehet erre nemzeti

\footnotetext{
Kapitány-Kapitány (2008) i. m. 3.

22 Hankiss Elemér: Proletár reneszánsz. Tanulmányok az európai civilizációról és a magyar társadalomról. Budapest, Helikon, 1999. 34-37.

23 Kapitány-Kapitány (2008) i.m. 4.

24 Durkheim (2004) i. m. 216.
} 
Himnuszunk. Ha a nemzeti imádságnak is nevezett zenemúvet énekeljük, hallgatjuk, résztvevőként mozgósíthat bennünk olyan emóciókat, amelyek nemzeti identitásunkat jelentik, és amelyek a történelemi szimbólumok és a szocializálódás során egymással összefonódó érzelmeket generálhatják. Amikor elemezni kezdjük, szembeállítjuk más himnuszokkal, leírhatjuk a más nemzetek himnuszaitól megkülönböztető jegyeit, ezeket értelmezhetjük a nemzeti történelem sajátos alakulásából, megállapíthatjuk a magyar költészet és zene alakulásának a Himnuszban ható sajátosságait, analizálhatjuk a Himnusz által kiváltott érzelmek lélektani skáláját. ${ }^{25} \mathrm{Ez}$ a magyarázata annak, hogy a jelképeket egyetemes objektivitásuk mellett szubjektív jelentéssel is felruházzák, ami esetenként a félreértelmezések alapja lehet. Amikor a jelenségekhez egyetlen jelentést társítanak (saját világfelfogásukat alapul véve) kiderülhet, hogy más jelentése is lehetséges egy-egy jelképnek, amely a használó számára esetlegesen kedvezőtlen. A társadalmat számos szimbólum osztja meg, az emberek bizonyos szimbolikus megoszlások mentén szövetségest vagy éppen ellenfelet láthatnak ugyanabban a másik emberben. A szervezetek szintjén vizsgálva: egy-egy futballklub mögötti szurkolótábor számára egy másik klub szimbolikája akár a velük való fizikai összecsapásba torkolló ellenséges érzést válthat ki.

A közösségi rítusok és az azokhoz tartozó szimbólumok azok, amelyek közösséget formálnak és a lelki tényezőt hozzáadják a nemzeti identitás fogalmához, és az embercsoportok összekötőivé válhatnak, állítja a szakirodalom. ${ }^{26}$ Buda (idézi Kapitány) olyan mintáknak nevezi ezeket az attitüdöket, amelyek „az összetartás bázisait, egyben kötelékeit is jelentik adott közösség tagjai között". ${ }^{27}$ Geertz értelmezésében a szimbólumokban megtestesülő jelentések, koncepciók segítségével az emberek kommunikálnak egymással, állandósítják tudásukat és attitüdjeiket. ${ }^{28} \mathrm{Az}$ ünnepek természetes törekvése, hogy az ünneplés időpontjában valamiféle csoportegységet teremtsenek meg. Más kérdés, hogy ez az egység sok esetben csak látszólagos, hiszen például a március 15-i ünnepségek különböző tereken folynak, s a helyszíntől, az időponttól meg a politikai-ideológiai preferenciáktól függően a közönség tagjai is mások. A magyar ünnepek másik példája, augusztus 20-a is azt mutatja, hogy a gyakorlatban a politikai közösség egységének megteremtése meghiúsul annak a ténynek a következtében, hogy az ünnepekhez az egyes társadalmi, politikai csoportok körében más-más tudattartalmak társulnak.

Edensor hangsúlyozza, hogy a szimbólumok nemcsak a közös múltból származhatnak, hanem a jelenből, így válhatnak például kulturális rendezvények vagy éppen sportágak, sportolók is nemzeti szimbólumokká. A magyar labdarúgás fénykorának ikonikus csapata, az Aranycsapat nemcsak nemzeti szimbólummá vált, hanem a sportág kedvelőinek körében olyan csoportképző szerepet is játszott, amely a magyar nemzeti identitás erősödésében összekovácsoló erőt képviselt. A szimbólumok szerinti csoportazonosulás kijelöli a másik csoport számára azon határokat, amely az azonosulási képesség elmaradása következtében a kirekesztéshez vezethet. A szimbólumok,

\footnotetext{
25 Kapitány-Kapitány (2008) i. m. 5-7.

26 Paár Ádám: A közösségi szimbólumok és rituálék szerepe a magyar nemzeti identitásban. Kultúra és Közösség, 7. (2016), 4. 37-39.

27 Kapitány-Kapitány (2008) i.m. 4.

28 Geertz (2001) i. m. 65.
} 
ha ilyen csoportazonosulást és elhatárolódást kifejező jelképekké lesznek, gyakran hívójelekként is müködnek. A mindennapi ütközések és szövetségek túlnyomó része éppen a szimbólumok nem azonos értelmezése körül bonyolódik - írja a Kapitány szerzőpáros. ${ }^{29}$

A modern kor embere kezdi újra felismerni a régi korok jelképeinek értékét, és jó esetben arra törekszik, hogy megértse a régi és új jelentéstartalom közötti összefüggéseket. Azonban gyakori jelenség, hogy a technikai civilizáció társadalmában élő ember a régmúlt szimbólumait az ősi jelentéstartalomtól eltérően, más értelmezésben használja.

Az ősi népeknél a tetoválás, az arc- és testfestés egyfajta üzenetközvetítő és veszélyt elhárító szerepet töltött be, általában a félelmet keltő, az életben maradásukra veszélyt jelentő vadállatok képét rajzolták testükre. Gyakran az adott közösséghez tartozás vagy egy közös lét időszakának emblematikus kifejezői a tetovált tartalmak. A történelmi visszatekintés igazolja, hogy a szociális közösséghez tartozás szimbólumokkal történő kifejezése korai eredetü. A primitív népeknél a totemizmusban az emberi testre történő tetoválás a közös létközösséget szimbolizálta. Az őskeresztények a testükre bélyegeztették Krisztus képét, később az együtt töltött évekre emlékeztető, megkülönböztető tetoválások tüntek fel az egy helyen szolgáló katonáknál, a tengerészeknél, valamint az egy fegyintézetben tartott raboknál.

Az emberi bőr korunkban is a különböző szimbólumokat hordozó felületté vált széles körben, kiváltképpen a fiataloknál. A test tetoválásának a divatjában megjelentek (vélhetően tudattalanul) a régmúlt emberének a pogány, sámánista tartalmakat hordozó szimbólumai (kígyó, madár, pillangó, halálfej, tigris stb). Ma egy tetovált sas biztosan nem az égi hatalom jelképe, és a tetováltatók nagy része nem szimbólumértéke miatt választja a ragadozó madár képét, hanem azért, mert tetszik neki. Egy-egy taszító külsejü szörny tetoválását sem azért kérik, hogy ezzel az önmagukban lévő szörnyet legyőzzék (a szörnyalakok a korai kultúrákban az állati én legyőzésének a szimbólumai voltak), hanem azért, mert a testükre örökre „felvarrt” szörnyek a társadalommal való belső szembenállásuknak a megjelenítői.

A sztálinista Szovjetunióban a rendszerrel való szembenállás kifejezésére a keresztény szimbólumokat felvonultató tetoválások szolgáltak. Amerikában a Harley Davidson motorkerékpárokat építő „művészek” sajátos szimbólumrendszerét a testükön összetekeredő kígyó jelképezi, de az állatnak nincs köze a Bibliában említett „paradicsombeli” kígyóhoz.

Mai világunkban gyakori, hogy az átörökített és nemes jelentést hordozó szimbólumokat kereskedelmi célokból profanizálják, tömegcikké alacsonyítják. Amíg a szimbólum betöltötte eredeti közösség-összetartó, a hétköznapi világot a szellemi világgal összekötő szerepét, addig a közösség tagjai számára normaként szolgált. A szimbólumok kereskedelemben való megjelenése a szimbólumok eredeti, veretes jelentéstartalmának a halálát hozhatják el, mivel az eddigi, mélyebb jelentést hordozó üzenet átalakult üres képpé, tetszetős ábrává, esetleg új jelentéssé. Jó példa erre, hogy ezer éve a kereszt vagy a hal arra utalt, hogy tulajdonosa keresztény. Ma egy vastag aranyláncon lógó aranykereszt tulajdonosáról a szemlélőnek biztosan nem a viselőjének a jelképpel való belső azonosulása jut eszébe, ahogy hal alakú medált sem feltétlenül

29 Kapitány-Kapitány (2008) i. m. 14. 
keresztények hordanak. Ez utóbbi - jelentésmódosulásának eredményeképpen - arra is utalhat, hogy viselője a halak jegyében született.

\section{Szimbólumok a szervezetben}

A modern társadalom emberének élete legtöbb vonatkozásban szervezeti keretek között zajlik, illetve csaknem minden szükségletének kielégitése szervezetek tevékenységének igénybevételével, közbeiktatásával történik. A munkavégzés mellett az oktatás, a gyógykezelés, a kulturálódás, szórakozás, sportolás, a közlekedés stb. során a társadalmat behálózó szervezetek sokaságával kerülünk kapcsolatba, jórészükkel rövidebb-hosszabb ideig azok tagjaiként.

Az utóbbi évtizedekben a szervezeti kultúra szerepének és jelentőségének taglalása során számos szerző példákkal kívánja bizonyítani, hogy a szervezet kultúrájának, a tagok által közösen vallott értékeinek nagyobb szerepe van a szervezet sikerességében, mint az egyéb tényezőknek. A szervezeti kultúra - a társadalmi kultúrához hasonlóan - jelképes rendszerek összességeként is meghatározható. A katonai rituálék, a díszlépés, a zászlófelvonás mint kulturális gyakorlat, egy jelképes rendszer jelentéshordozó részei. A szimbólumok megkülönböztető, jelentéshordozó ereje miatt a szervezetek és intézmények mindinkább fontosságot tulajdonítanak a szimbólumok széles körü alkalmazásának, a szimbólumok nyelvezetét célirányosan használják az értékeik, előfeltevéseik megjelenítésére. Hofstede, miként Daft is, a szervezeti kultúra illusztrálásaként egy hagymához hasonlítja azt, amelynek három rétegét különbözteti meg. A legfelső szinten találhatók a megfigyelhető kulturális képződmények, a szimbólumok, mint a látható viselkedés, a használt nyelvezet és alkalmazott szakzsargon, öltözködés, a szervezeti ünnepségek és szertartások, a szervezet fizikai megjelenése (például a tárgyak és berendezések, a logó). ${ }^{30}$ Ezekből a jegyekből több-kevesebb biztonsággal következtethetünk a szervezeti kultúra tényleges tartalmára, mélyebb rétegeire, mint az értékek, feltevések, szervezeti filozófiák, amelyek azonban láthatatlanok maradnak. A szimbólumok jelentős része könnyedén észlelhető külső szemlélődők által, azonban azok jelentése - a fentebb idézett habermasi gondolatnak megfelelően - csak a kultúrához tartozók számára érthető.

Minden szervezet rendelkezik megkülönböztető jegyekkel, így tudják a kívülállók elkülöníteni a többi, a hasonló szervezettöl. Valamennyi szervezet számára fontossággal bír a minél jobb felismerhetőség, az azonnali beazonosithatóság, a konkurens vagy társszervezetektől történő elhatárolhatóság, ezért tudatosan törekednek egységes és egyedi arculatuk kialakítására. Sok esetben az emberek tudatáig rövidebb úton lehet eljutni szimbólumok használatával, mint kommunikációval, a materiális, vizuális és nyelvi szimbólumok rendszere a szervezetazonosság megteremtőjeként tud funkcionálni. Adott szervezet identitásából fakadó szervezeti formavilágot összességében megjelenítő vizuális jegyek hatékonyan fejezik ki a szervezet egyediségét. Egy embléma, egy zászló, a szín- és formavilág használatával (az egyszerű és egyértelmú információközléssel) szimbolizálni tud valamely nézetet, a képviselt érékeket, a cégfilozófiát.

30 Bakacsi Gyula: Szervezeti magatartás és vezetés. Budapest, Aula, 2004. 227-229. 
Logókat is ezért kezdtek el használni, hiszen a logó által felismerhetővé válik a márka, a logóhoz egy kapcsolódó jelentés társulhat. Szimbólumok tudják biztosítani a szervezet arculatának térbeli azonosságát is, általuk ugyanúgy tud megjelenni más-más földrajzi helyen vagy különböző kulturális környezetben.

A szervezeti szimbólumok mind kifelé a külső környezet, mind befelé a tagok irányába többletjelentést is hordoznak, miután asszociatív erejüknél fogva nemcsak helyettesítik a kifejezendő tartalmat, hanem vele kapcsolatban különböző érzéseket és hangulatokat képesek felidézni. A tagok esetében „a megragadható jellemzők azért különösen fontosak, mert ezeken keresztül sajátítják el a kultúrát, megfigyelésük orientálja a kívánt viselkedésminták kialakítását, a ceremóniákban való részvétel és a történetek megerősítik az elért magatartásváltozásokat". ${ }^{31}$ A szervezet rendszerében mindezeket a szocializáció folyamatán ismerik meg, majd mint használói és értelmezői jelenítik meg, és magától értetődő természetességgel alkalmazzák az adott szociális közeg sajátos nyelvezetét, kategóriáit és fogalomrendszerét. E folyamatot elősegíti, hogy „a szimbólum kulcsszerepet játszik egyén és csoport, egyén és társadalom összekapcsolásában" - véli Pataki. ${ }^{32}$ A közösen értelmezett és használt szimbólumrendszer összefoghatja a csoportot, s a szervezethez való tartozás szoros kifejezését is mutatja. A jelképek használóit hozzásegíti úgy a szúkebb, mint a tágabb szervezeti közeg jellegzetességeinek megismeréséhez. A szervezetek esetében is megfigyelhető a szimbólumok egységesítő és elválasztó jellege. A közösen, a korábbi jelentéssel értelmezett szimbólum összeköti mindazokat, akik számára ez evidens, és használói számára olyan egyezményes jelek, amelyek a közös szervezeti identitásuk alapja, ugyanakkor elválaszt azoktól, akik számára e jelképek nem evidensek. Így a jelképeknek az értelmezési különbségeik alapján erős kohéziós szerepük van a csoportokra nézve.

A szervezeti szimbólumok - ellentétben az egyetemes archetípusos szimbólumokkal (mint például az élet, a termékenység, a gonosz erői), amelyek spontán módon, a társadalomban „szervesülve” keletkeztek - többnyire tudatos folyamatok eredményeként születnek, szándékosan létrehozottak, valamilyen célra kijelölt szerep húzódik kialakulásuk mögött. Elsősorban az alapítóknak van lehetőségük arra, hogy az általuk képviselt értékek váljanak a szervezeti folklór részévé, s a személyes példáik, történeteik lesznek a későbbi generációk gondolkodásmódját is befolyásoló legendákká, mítoszokká. Az alapítók által kialakított kultúra hosszú időn át képes fennmaradni, átörökítődni, annál is inkább, mert a különböző szervezeti események, ceremóniák által tudatosan életben tartják az értékrendet és a tradíciókat.

Egyed utal rá (idézi Szabó), hogy a szimbólumok idővel veszíthetnek érzelmi, affektív komponensükből, és ekkor már csak egy „helyettesítő” marad, és a tárggyal való érzékelő és érzelmi hasonlóságtól megfosztódik. Ekkor a szimbólum a jelek felé halad, miközben elveszíti az eredeti érzelmi töltést, amely benne feszült. Szimbolikus gesztusként az egykori görög vagy germán harcosok levették a sisakjukat, hogy megadják magukat a győztes ellenfélnek, elismervén győzelmüket. Ennek kései utánzata az, amikor ma azt mondjuk valakinek tette elismerése jeléül, „emelem a kalapom”. Az eredetileg mindenki előtt ismert és világos szimbólum elhomályosodott, a tiszteletnek, elismerésnek a jelévé

\footnotetext{
Bakacsi Gyula: A szervezeti magatartás alapjai. Budapest, Gondolat, s. d.

32 Pataki Ferenc: Az én és a társadalmi azonosságtudat. Budapest, Kossuth, 1982. 289.
} 
változva át. ${ }^{33}$ Hasonló gesztusmódosulás eredményeként alakulhatott ki a jól ismert katonai tisztelgés, bár története nem pontosan feltárható. A legendásnak ítélt változat szerint a középkori lovagok fejvédőjének rostélyát húzták fel, amikor üdvözöltek valakit (és hogy felismerjék egymást), ennek a gesztusnak a maradványa a mai tisztelgés. Más vélemény szerint, egyszerüen a kalap levételének, mint a köszönéshez párosuló tiszteletet adó mozdulatnak a leegyszerüsített, szimbolizált formája (mint ahogy meg is maradt, hogy a kalap szélére nyúlnak egy gyors tiszteletadás okán).

A szervezeti szimbólumok között megkülönböztethetők a természetes és a mesterséges szimbólumok. A fizikailag is megjelenő, materiális „üzenethordozók” a természetes szimbólumok közé tartoznak: az épített környezet, benne az épület, az udvar, s ezek konfigurációi, az egyenlőséget-egyenlőtlenséget kifejező irodaberendezés, a nyitottságot jelképező egylégterủ munkahely, a műalkotások, a cégfilozófiát tükröző dinamikus logó. A szimbólumok egyszerü mértani alakzatokból és színekből építkeznek, amelyek viszont már maguk is rendelkeznek jelentésekkel. Míg a kör - mint önmagába záródó végtelen vonal - az örökkévalóságot és a világ végtelenségét jelenítheti meg, addig a négyzet (mint általában a szimmetrikus, arányos, szögletes formák) szabályosságával a világ rendjét, szilárdságát, a nyugalmat, az egyensúlyt képezi le. A szervezetet szimbolizáló fizikai megjelenésre példa a laktanyák épületeinek sarkos elrendezése a szögletes épületek által közrefogott alakulótérrel, amely - már fizikai valójában is - a katonai szervezetre jellemző rendezettséget, szabályozottságot, fegyelmezettséget szimbolizálja.

A szervezeti szimbolikában a színeknek is igen meghatározó a szerepük, mivel a színek közvetlen módon keltenek bennünk érzelmeket. A vörös az életerő, vér színe (a tűz és a háború mellett), ezért fogalmazódott meg a piros kereszt a harcban megsebesült katonának nyújtott segítség jelképeként (1863-ban) a Nemzetközi Vöröskereszt szervezet szimbólumának. A szín- és formavilág mint megkülönböztető és egyben a csoporthoz tartozást kifejező szimbólum szerepe hangsúlyosan jelent meg a korábbi évszázadok haderőiben. A különböző ezredek beazonosíthatók, illetve egymástól megkülönböztethetőek voltak, ${ }^{34}$ miután az egyes ezredeknek eltérő volt a ruházatuk. A színszimbolika a későbbiekben, az egységes egyenruhát viselö hadseregben is megmaradt, de ekkortól már a (vállapon vagy galléron megjelenő) megkülönböztető vonása a fegyvernemhez tartozást jeleníti meg (a fegyvernemi jelvénnyel együtt), s nem véletlen, hogy például a piros szín a tüzérek, a zöld(mező) szín a lövészek (gyalogság) színe lett. A zászló mint erős szimbólum, nemcsak képi- és forma világával, de még a méretével is „üzenet" hordozó volt, a kisebb méretű zászló a mozgékony lovasságot, míg a nagyméretű zászló a (nehezebben észrevehető) gyalogságot jelezte.

A forma és a szín együttes szimbolikája erős üzenetet és érzelmi töltést hordozhat. Ezt jól példázza, amikor erre az egyesült erőre épített egy szervezet és a piros tulipánt választotta szimbólumának. (Ráérezve a kor és az események aktualizáló szerepére.) E virágot sokan ősi magyar jelképnek tartják, amelynek bizonyítékául a tulipános életfa létezését tekintik, $\mathrm{s}$ amely virág egyben a természet megújhodását is jelzi. A tulipán évszázadok óta a magyar népmúvészeti ábrázolás valamennyi területén jelentős

Szabó (2012) i. m. 53.

34 A parancsnok számára ennek funkcionális jelentősége különösen a harcok idején volt nagy. 
szerepet kapott, ${ }^{35}$ alkalmazása a múlt értékeinek őrzését, történelmünk ápolását fejezte ki. Másrészt a virág tölcséres kelyhét a nőiesség kifejezőjének, egyben az újjászületés, megújulás jelképének tartják.

A természetes szimbólumok sorába tartoznak a rendszeresen ismétlődő, különböző ceremóniák, szertartások, amelyek megjelenítik a fontos szervezeti célokat, megerősítik a szervezet alapértékeit, megemlékeznek a szervezet értékeit képviselő „hősökről", kiemelkedő korábbi személyiségekről, vezetőkről. Az ünnepségeken túl a szervezeti filozófiák, előfeltevések olyan természetes szimbólumokban öltenek testet, mint a szervezeten belül keringő történetek, legendák, mítoszok. E szimbólumegyüttesek látványosan jelenítik meg az elvárt magatartást, a kívánatos értékek szerinti cselekvést. Az ünnepségek (vizuális és zenei elemek által növelt) érzelmi komponensük folytán még inkább erősítik a közösség tagjai közötti köteléket. E ceremóniák szimbolikus jelentéshordozók, legyen az diplomaátadó, iskolai ballagás, katonai tisztavatás, a szervezet alapításának évfordulója, a különböző beiktatási és felavatási ünnepségek. Megfigyelhető, hogy a szervezetek mindinkább kiaknázzák a közös rendezvények csoportteremtő erejét, a munkához és a nem munkához kapcsolódó élmények közötti tradicionálisan meglevő határvonal elmosódni látszik, a szervezeti kirándulások, sportrendezvények vagy (a korábban családi körben megtartott) újabb ünnepségek szervezeten belüli meghonosítása által. Hideg szerint a vállalati karácsony jelensége, amely rituális gyakorlatokat és mitikus elemeket tartalmaz, szimbolikus jelentéstartalma miatt kulcsfontosságú. „Ezek a ceremóniák azt a célt szolgálják, hogy a vállalat különlegességébe vetett »szent hitet« megerősítsék. A karácsonyi parti explicit célja, hogy a munkatársak közösen ünnepeljenek, de a felszín alatt láthatóvá teszi a vállalati ideológiát: a cég egy morális, gondoskodó kapcsolati hálót nyújt a munkavállalók számára."36

A mesterséges szimbólumok széles tárházába tartoznak: a nyelvi szimbólumok, a külső megjelenés, öltözködés (egyenruha, szervezet-feliratos ruha, sapka), az identitás egyéb vizuális szimbólumai, színei, betütípusai, a kiadványok, az emblémák és a napjainkra jelentőségre szert tett honlapok. A kultúra bármely alkotása, de különösen a nyelvben élő kultúra alkotásai bővelkednek szimbólumokban. Minden szervezetben van egy oda tartozó, arra a szervezetre jellemző „szótár”, szókincs, amelyet a tagok használnak, és amely alapján könnyen felismerhető, ki tartozik a szervezetbe, ki nem. A nyelvi szimbolika része a sajátos jelmondat, idézet, dal, mottó, amelyek ugyancsak egyedi jelek, gondoljunk csak a hadseregben alkalmazott jelmondatokra. A nyelvezeti szimbolika jelentőségét mutatja, hogy a fegyveres szervezeteket minden más szervezettől megkülönbözteti a „harci” szóhasználat és az ehhez kapcsolódó szimbolika.

Összegzésképpen levonható az a konklúzió, hogy a szimbólumok, természetükből következően mindig nyitva állnak az újabb, az adott korszak értékrendje szerinti átalakulások előtt. A jelképek jelentéstartalmának aktuális változása mindig tükrözi az adott társadalmakra jellemző norma- és értékrend minőségét. A szimbólumok kettős szerepe egyrészt biztosítja a közösség számára az egyéni tapasztalatok hasznosulását,

35 E motívum megjelent a székely fakapukon, a kalocsai hímzésben, a korondi fazekasok edényein és a lányok kelengyés ládáján is, ez volt az úgynevezett tulipános láda.

36 Hideg Anna Laura: Kritikai emberi erőforrás menedzsment A szervezeti életvilág szimbolikus szerkezeteinek újratermelése a vállalati karácsony kolonizációjának esetén keresztül. PhD-értekezés. Budapesti Corvinus Egyetem Gazdálkodástani Doktori Iskola, 2015. 106-114. 
másrészt az egyének számára a társadalom nézőpontjának átélését és elfogadását teszik lehetővé. Ez a kölcsönösség lehet a közösségek és az egyén számára is az a segítség, amely mind a társadalom, mind a szervezetek bonyolult folyamatainak a szimbólumokon keresztül való megismerését lehetővé teszi. A szervezetek világában a materiális, vizuális és nyelvi szimbólumok rendszere a szervezetazonosság megteremtője, egyben célirányosan használt eszközei a szervezet értékei, előfeltevései megjelenítésének. A szervezeti kultúra tudatosan létrehozott jelképes rendszereivel a kívülállók számára a megkülönböztető jegyeit, egyedi arculatát teremti meg, míg a szervezet tagjainál kulcsszerepet játszik a közösségbe történő integrálódás során.

\section{Felhasznált irodalom}

Bakacsi Gyula: Szervezeti magatartás és vezetés. Budapest, Aula, 2004.

Bakacsi Gyula: A szervezeti magatartás alapjai. Budapest, Gondolat, s. d. Online: https:// regi.tankonyvtar.hu/hu/tartalom/tamop425/2011_0001_543_07_A_szervezeti_magatartas_alapjai/adatok.html

Bodnár-Király Tibor: A magyar korona jelentésének színeváltozása a kora újkorban. Századvég, 15. (2009), 54. 149-156. Online: www.academia.edu/31381754/A_ magyar_korona_jelentésének_színeváltozása_a_kora_újkorban

Cassirer, Ernst: A szimbolikus formák filozófiája. In A jel tudománya. Budapest, Gondolat, 1975. Online: www.communicatio.hu/horanyi/DF-S-0910osz/A\%20jel\%20 tudomanya.pdf

Csörgő Zoltán: A szimbólumok és szertartások szerepe a modern kori ember életében. Debrecen, Debreceni Kossuth Lajos Tudományegyetem, Posztgraduális Mentálhigiénikus Képzés, 2011. Online: https://elitmed.hu/ilam/gondolat/a-szimbolumok-es-szertartasok-szerepe-a-modern-kori-ember-eleteben

Durkheim, Emile: A vallási élet elemi formái. A totemisztikus rendszer Ausztráliában. Budapest, L'Harmattan, 2003.

Edensor, Tim: National Identity, Popular Culture and Everyday Life. Oxford - New York, Berg, 2002. idézi: Dancs Katinka: A nemzeti szimbólumok és a nemzeti identitás ismeretjellegü elemei. Történelemtanítás, 2018. Online: www.folyoirat.tortenelemtanitas.hu/2018/11/dancs-katinka-a-nemzeti-szimbolumok-es-a-nemzeti-identitas-ismeretjellegu-elemei-i-09-03-06/

Geertz, Clifford: Az értelmezés hatalma. Antropológiai írások. Budapest, Osiris, 2001. Habermas, Jürgen: A kommunikatív cselekvés elmélete. Kézirat. Budapest, Eötvös Loránd Tudományegyetem, 1985.

Hankiss Elemér: Proletár reneszánsz. Tanulmányok az európai civilizációról és a magyar társadalomról. Budapest, Helikon, 1999.

Hideg Anna Laura: Kritikai emberi erőforrás menedzsment. A szervezeti életvilág szimbolikus szerkezeteinek újratermelése a vállalati karácsony kolonizációjának esetén keresztül. PhD-értekezés. Budapesti Corvinus Egyetem Gazdálkodástani Doktori Iskola, 2015 Online: http://phd.lib.uni-corvinus.hu/921/1/Hidegh_Anna_dhu.pdf 
Jung, Carl Gustav: Mélységeink ösvényein. In Az anyaarchetípus lélektani aspektusai. A szimbólumok szerepe. Budapest, Gondolat, 1993. Online: https://docplayer. hu/2382234-Melylelektan-keszult-jung-es-masok-muvei-alapjan.html

Kapitány Ágnes - Kapitány Gábor: Résztvevő megfigyelés a saját társadalomban - korszakok szimbolikája. In Boglár Lajos - Bodrogi Tibor - Ecsedy Csaba - Hofer Tamás - Marót Károly - Hoppál Mihály - Sárkány Mihály: A magyar kulturális antropológia története. Budapest, Nyitott Könyvmühely, 2008. Online: https:// szociologia.tk.mta.hu/uploads/files/archive/Kapitany_Resztvevo_megfigyeles.pdf

Kapitány Ágnes - Kapitány Gábor: Szimbólumelemzés a saját társadalom antropológiai kutatásában. In Kapitány Ágnes - Kapitány Gábor (szerk.): Jelbeszéd az életünk 2. Budapest, Osiris, 2002. 124-156. Online: http://real.mtak.hu/17583/19/szimbolumelemzes.pdf

Mohai Zsófia: A középkor szimbolikája. Ars Ensis, 2015. Online: www.arsensis.hu/pdf/ S3_15_MZs.pdf

Paár Ádám: A közösségi szimbólumok és rituálék szerepe a magyar nemzeti identitásban. Kultúra és Közösség, 7. (2016), 4. 37-58. Online: http://real-j.mtak.hu/11486/4/ KEK201604.pdf

Pál József - Újvári Edit: Jelképek, motívumok, témák az egyetemes és a magyar kultúrából. Szeged, Balassi, 2005. Online: www.balassikiado.hu/BB/netre/Net_szimbolum/ szimbolumszotar.htm

Panofsky, Erwin: A jelentés a vizuális müvészetekben. Tanulmányok. Budapest, ELTE BTK Müvészettörténeti Intézet, 2011. Online: http://arthist.elte.hu/TAMOP_412/3_4_ panofsky.pdf

Pataki Ferenc: Az én és a társadalmi azonosságtudat. Budapest, Kossuth, 1982.

Preglau, Friedold: Szimbolikus interakcionizmus - George Herbert Mead. In Julius Morel-Eva Bauer-Meleghy Tamás-Heinz-Jürgen Niedenzu - Mac Preglau - Helmut Staubmann: Szociológiaelmélet. Osiris, Digitális Tankönyvtár, 2000. 67-79. Online: http://venus.arts.uszeged.hu/pub/tarsadalomelmeleti/szociologia/katona/mead/ mormead.pdf

Ricoeur, Pierre: A hermeneutika elmélete. Tanulmányok. Auerbach, Palmer, Ricoeur, Hirsch, Szondi, Frye, Kermode - szöveggyüjtemény. (Fabiny Tibor szerk.) Szeged, JATEpress, 1998. Online: www.arsensis.hu/pdf/S3_15_MZs.pdf

Szabó Réka: Metaforák és szimbólumok: C. G. Jung szimbólumértelmezése és a fogalmi metaforák elméletének összevetése. PhD-értekezés. Pázmány Péter Katolikus Egyetem, 2012. Online: https://doi.org/10.15774/PPKE.BTK.2014.002

Váraljai Julianna: Egyiptomi szimbólumok, amiket ma is használunk. HarmoNet, 2019. december 15. Online: www.harmonet.hu/ezoteria/72321-egyiptomi-szimbolumok-amiket-ma-is-hasznalunk.html

White, Leslie: Az energia és a kultúra evolúciója. In Kisdi Barbara: A kulturális antropológia története, elméletei és módszerei. Egyetemi jegyzet. Budapest, Pázmány Péter Katolikus Egyetem - Akadémiai, 2012. Online: https://btk.ppke.hu/uploads/ articles/4090/file/kisdi_barbara-kulturalis_antropologia.pdf 